\title{
Industrial Relations between Ojek Online Drivers with PT. Gojek Indonesia Branch of Surakarta
}

\author{
Devi Intan Chadijah', Mahendra Wijaya ${ }^{2}$, Raden Bagus Soemanto ${ }^{3}$ \\ 1,2,3 Sebelas Maret University \\ Email: intanchadija@gmail.com
}

\begin{abstract}
This study to analyze about understanding the driver and the company of Gojek about Partnership Agreements which is different with Work Agreements that has been set up by labor law in Indonesia, so it became a new study, and then analyze to know the relation that partnerships between the driver, company, government and consumer. This research is assessed using the theory social exchange Peter Blau. The method of this study is naturalistic inquiry. We find there is a different understanding between the driver with the company of Partnership Agreements. According to the drivers, contract offered by the company Gojek have not answered the rights of driver as a partner or as worker, like social security, a system of compensation, and working time. Partnership Agreements that should have mutually beneficial, but in fact a working relationship which is interwoven as a working relationship on workers that have must always be subject to any company policy. Therefore the drivers agree if online transportation of ojek arranged by the government. The absence of a labor union official and there is no industrial relations commonly called Tripartite between the driver, company, government and consumer.
\end{abstract}

Keyword: Industrial Relations; Partnership Agreements; The Rights of Workers; Online Ojek Transportation; Gojek

\section{Introduction}

The limited job opportunities in formal sector reform the people looking at other alternatives like the informal sector. This aims to meet the needs of its economy. Generally the informal sector do not have social security is facilitated by the employer, but this was not the halting intention for workers 
who don't have the ability to work in the formal sector. Data from the Central Bureau of Statistics in 2018, indicate roughly $58 \%$ the amount of labor in indonesia took the lead is the informal sector. The number of informal sector workers is greater than workers in the formal sector. Therefore, the informal sector jobs are considered to be more rapidly than employment growth in formal sector reform.

Not many of the intervention of a government against, informal sector the government focus on workers in the formal sector. As a result, the informal sector wasn't capable of being raised in bargaining position workers better welfare standard, even have to find out how to survive. On the other side, the existence of the informal sector isn't inferior on all fours with the formal sector in encouraging the development continuity and the whole economy.

One of the field work in informal sector which is being demanded by the breadwinner is to be ojek online drivers. One whose business services of ojek online hot issue right now is Gojek. Service industry it began operations in the city of Surakarta in may 2016 with the income promising and far greater than conventional transportation, put the target Gojek job opportunities for the breadwinners. Some only joined as a partner to work with side, but there are also some who work fulltime and become the main livelihood for his family.

Gojek is one based company ridesharing and ridehailing with a system of sharing economy. The system is based on the role of a share of the revenue that is mutually beneficial to both parties. Like other companies, PT. Gojek Indonesia also has an agreement as a guideline cooperation between the company with their partners namely the driver. Work agreements be offered the partnership agreements. This is very different with the UndangUndang Ketenagakerjaan in general have rules working time, wages, social security and social facilities with a view so that workers feel comfortable for work, and can increase productivity performance. Partnership agreements offered by the company to the driver which isn't having hours or come home from work for sure, there is no guarantee social and not provided social facilities as a place to stop or to rest for the ojek online drivers.

Partnership agreements between companies gojek with the driver is to use a sharing economy system, namely $90 \%$ for the 
driver and $10 \%$ for the company. Because of that , according to Lora (2018:69) it is perfectly natural to companies did not facilitate in their entirety about social security and social facilities for the driver. The relationship between gojek and drivers in partnership agreements is not an employment relationship which is usually in general the existence of a party boss (employer) and the subordinate (laborer), so if his position as a worker then he should get the full facilities from the company. It was because, the partnership agreements does not meet the wages and command were elements of a cooperative relationship (Lora,2018:78). Partnership agreements of Gojek is a work that puts forward on the basis of partnership with the mutual benefit of each other. But based on the field findings on the driver gojek in Jebres District at Surakarta City, there are several cases have according to the ojek online drivers are very injurious to his side. It was because the parties the driver consider their position as a partner. One of them is as the slow process of transactions in the bank accounts of driver, that there were some changes of any tariff or suspend suddenly of company without notice and consensus with the driver.
In this case, partnership agreements that should benefit each other, have a parallel position, there are no positions such as superiors or subordinates, but without realizing it, there is an unequal relationship in which the drivers require that they always comply with any policy and not given space to consult before changing existing policies.

\section{Literature Review}

In this discussion, there are several conceptuals such as industrial relations, Partnership Agreements and social exchange theory from Peter Michael Blau.

\section{Industrial Relations}

According to labor law No.13 in 2003 chapter 1 paragraph 16 , industrial relations is a system relationships formed between actors production of goods or services comprising of elements entrepreneurs, workers, and the government based on values Pancasila and the Undang-Undang of the Republic of Indonesia 1945. Interested parties in those relationships, namely workers a businessman, as well as a labor organization, employers organization, government and the community as a consumer (Suprihanto,1992:29). The relationship 
need to ensure are kept and developed in the interests of all parties involved. The purpose of training or the development of industrial relations is to create a secure relationship and harmonious between parties is to increase productivity business (Simanjuntak,2003:25). Thus, industrial relations management is one of the development of human resources management.

One from management at the company is industrial relations has formulated regulations corporation or partnership agreement which contain rights and obligations of workers and the authority and obligations of employers. The rights of workers is fulfillment of an obligation entrepreneurs. An obligation workers based on the authority employers to take care of that. The workers a job in accordance with the leaders to work and discipline in the work that has been set up. In return for the employment services it, workers eligible for wages, allowance and other social security, rest, on leave, fight for their rights directly or indirectly through the union. In addition to the workers are entitled to various kinds of protection, such as the protection of the health and safety, protection of the right to associate and negotiate with employers, as well as the protection of wages and incomes at the time were unable to do the job (Suprihanto,1992:31).

Industrial relations started from the working relationships were more in the nature of individual between employers and workers. Setting the rights and obligations workers governed by an employment agreement. This work agreement is carried out at the time of receipt of workers, among other contain provisions related to the extraction time, the problem of probation, office concerned, salary or wages, facilities available, the responsibility of, job description and work placement (Batubara,2008:63). In industrial relations both the company and workers has the same right and legitimate to protect matter considered as their interests each, also to secure their aims. Thus industrial relations is legality of an official nature. On the one hand, workers and entrepreneurs have the same interests, which is survival and progress company, but on the other hand the relationship between they also have the potential conflict, especially if both relating to the perception or interpretation who do not same points about the interests of each side (Batubara, 2008:67).

Industrial relations involves a number of the concept, for example 
the concept of justice and equality, power and authority, individualism and collectivity, rights and obligations, and integrity and trust (Djokopitojo,1994:92). This is in line with the elements contained in the social exchange theory which is used as a problem analysis tool in this study. Meanwhile, the main function of the government in Industrial Relations is to establish or compile labor laws and regulations so that the relationship between workers and employers goes hand in hand and is balanced, based on the regulation of fair rights and obligations (Batubara,2008: 69). In addition the government also obliged to finish fairly dispute or conflict. Basically, the interests of the government also to maintain the sustainability of the production process in the broader. According to Simajuntak (2003:55), the ultimate goal of industrial relations is to increase productivity and their welfare and entrepreneurs. Both these goals are intertwined, not separate, even affect each other. Productivity a company that was preceded by work productivity of its employees can only occur if the company supported by the workers prosperous.

According to Batubara (2008: 71) the key success created a safe and dynamic of industrial relations is communication. With maintaining the a communication that in an orderly fashion are both sides, the workers and employers, will to be able to draw a tremendous benefit. The main supporting this communication is a good positive interaction between employers and workers. This kind of interaction and maintained regularly and sustainable will create mutual understanding and trust. Both of these are dominant factors in creating work calm and entrepreneurship or also called industrial peace (Batubara, 2008:83). For workers communication can be used to know early and deep about the state of the company and the company in the future. In addition, workers can also convey their various views to help improve company performance. This kind of thing to be taken positively by the management of the company, as well as be recognition and appreciation to workers who care the company.

In this case, the relationship that is built between Gojek drivers and Gojek companies has not yet had official industrial relations such as bipartite and tripartite. Bipartite relationship is a relationship between two parties namely the workers and the company, while 
tripartite is between three parties, namely workers, companies and the government. The relationship between the Gojek driver and company is still informal, but not familial. The relationship that exists is still a gap between the driver, the company and the government. Based on field findings, all the main informants (Gojek drivers) wanted the Gojek company to be regulated under the auspices of the government. This is so that the driver gets the rights that are worthy of being accepted as workers, so that the partner status offered by the Gojek company can be an employee status under the authority of the government.

There are three elements that supports the achievement of the aims industrial relations, namely the first, rights and obligations guaranteed and implemented. Second, if a dispute arises, it can be resolved internally (bipartite). Third, strike by workers as well as closing company (lock out), by employers, should not need to be used to impose the will of each other, because the disputes that occurs can be solved well.

\section{Partnership Agreements}

According to Umar Kasim in Lora (2018:29) the partnership agreement is a general form a legal relationship between one party and another party on the basis of a partnership agreement. Forms of agreements do work on the basis of partnerships, namely: profit sharing agreements, agency agreements (in person or corporation), core-plasma, sub-contracts, payment agreements (deposits) for a certain amount of money, and others. Therefore, the partnership agreement puts forward a mutually beneficial relationship between the parties so that the position of the parties is the same. Whereas, in a work agreement, it contains elements of work, wages, and orders where the position of the employer as the boss and the employee as subordinates.

In the relationship of work agreements, workers have rights in general, which partners do not have in partnership relationships such as overtime wages (additional wages given in the event of additional working hours than specified), health insurance, and old age benefits if the employment relationship ends (Sovia in Lora,2018:33). In this case, relationship between the application provider company Gojek and drivers is a partnership relationship based on a partnership agreement. Partnership agreement PT. Gojek Indonesia with drivers 
does not fulfill the characteristics and elements of work agreements such as wages, orders and elements of work. Based on the attachment to the contents of the partnership agreement, it has also been mentioned that Gojek drivers act as partners. Not only that, the drivers do not get a salary from the Gojek application company but the ojek drivers must share their income with the company. Gojek drivers income itself depends on how many passengers place an order through the application and the willingness of the driver to deliver services according to passenger demand.

\section{Social Exchange Theory}

The theory used in this study is the social exchange theory from Peter Michael Blau. Blau focuses on problems that originate in social processes, which regulate very complex social structures from more fundamental processes that extend to the daily activities of relationships between individuals and their interpersonal relationships (Ritzer, 2014: 192). Blau places power, domination, and conflict of interest as the center of his analysis.

Man was born as individuals interconnected to each other, so that they also interdependent and affect one another. Therefore, in fulfillment of the needs of his life. man must exchange needs, Even is not limited in just the materialistic, but also social needs so as to form a social bond. These exchanges build on the purpose to be achieved by each the drivers of Gojek and the company of Gojek.

The concept of social exchange that was mentioned by Blau, the limit on the act of that depends on reaction from others namely action that will be lost when a reaction that is expected to follow up appear. According to blau, the attracted to each other for various reasons that drives they build social association. When the initial bond is built, return given to each other serves to maintain and strengthen ties. The exchanged rewards can be intrinsic (example love or respect) or extrinsic (example money or physical labor). Each party cannot always provide equal compensation. When inequality occurs, differences in power will appear. This supported by statement Blau in Ritzer (2014:198):

To speak of social life is to speak of the association between people, their associating in work and in play, in love and in war, to trade or to worship, to help or to hinder. it is in the social relations men establish 
that their interest find expression and their desires become realized.

The links between theory and problem in this study is generally social relations consisting of some individuals. Each individual has behaviors that influence each other in the relationship where there are elements of rewards, beliefs, profitloss rationales, values, norms, power, dominance and conflicts of interest that has each party. The Gojek company offers a work system such as profit sharing with a percentage of $90 \%$ for the driver and $10 \%$ for the company, besides that the company also provides bonuses to drivers who have high work productivity. The rights and obligations of the Gojek only manage the application and monitor the order of the order.

\section{Methodology}

This study uses naturalistic inquiry. In naturalistic inquiry researchers are the main key in collecting and interpreting data. Informants are treated as subjects and their relationship with researchers is interactive. The location of the study was conducted in Surakarta City in Jebres, this is because the city of Surakarta is a city of culture and strongly supports conventional transportation such as becak, ojek pangkalan or kosti (local taxi). The beginning of the entry the Gojek at Surakarta in may 2016 is a denial of Surakarta city government, and is only allowed for deliver goods is not to take passengers. But over time, now motorcycle online of Gojek develop rapidly and to transport most favorite in the city of Surakarta, either as transport drivers or as consumers. As for several reasons for Jebres as research sites is administratively. In Jebres is in both widest and having most populous second populated in Surakarta. Jebres sub-district also has many potentials such as tourism, education and industrial areas. The many potentials of Jebres also support the high mobility of people in this region, and have an impact on the number of interested people use Gojek and into the driver Gojek while around the region.

Informants in this study consisted of Gojek drivers, Gojek companies, communities as consumers and Government of Surakarta City. Informants was selected based on the basis that informants to reflect themselves and business partner. The informant retrieval technique uses purposive sampling. Data validation involves thorough triangulation, which includes information sources (informants) and data collection 
methods. Data was collected through participatory observation, in-depth interviews, and interactive model data analysis. Miles and huberman (1994:88), suggested that activity in qualitative data analysis was conducted in interactive place in a continuous until complete, so the data is saturated. The size of data saturation is indicated by no new data or information obtained. Activities in the analysis of this model include data reduction, data display, conclusion drawing/ verification.

\section{Result}

The research result refers to the formulation problem in this research namely to know meaning of Ojek Online Drivers and PT. Gojek Indonesia in Partnership Agreements. In this case, information will be obtained in depth about the rights and obligations of each party in the Partnership Agreements, and to find out the industrial relations between Ojek Online Drivers and PT. Gojek Indonesia. In this case also knows the relationship between the two parties to the role of the Government and the role of the community as consumers.

1. The Meaning of Ojek Online Drivers and PT. Gojek Indonesia in Partnership Agreements
In this case, to answer these problems, researchers collect information about the rights and obligations of each party in Partnership Agreements. Based on field findings, there are differences in understanding between the driver and the company on the Partnership Agreement, the driver feels the employment contract offered by the Gojek company has not answered the rights of the driver as a work partner or even as a worker who facilitates social security, wage system and working time arrangements.

But according to the company of Gojek, the company considers the distribution of 90:10 made by Gojek with the partnership agreement has greatly benefited the driver. But most of the Gojek drivers said that the cooperation system offered by Gojek was still detrimental to the driver. This is because the partnership agreement made is not based on the results of a mutual agreement. This agreement is made by the Gojek company. So that any policies offered must be forcibly followed. The driver considers their position as a partner, not a worker. So 
they feel that the partnership cooperation system offered by Gojek like a system of employee cooperation. If indeed the cooperation that is built leads to the work system of the employee, the driver wants to get the right to social security, such as accident, health, death and pension plan.

2. Industrial Relations between Ojek Online Drivers and PT. Gojek Indonesia

In this case, to answer these problems, researchers obtain information to know relations between the two parties with the government role and roles of the people as consumers. The working relationship that exists between the driver and the Gojek company, is a work relationship such as for workers who must always submit to any company policy, not the appropriate partner relationship. In this case the partnership agreement which should be mutually beneficial to each other, have a parallel position, there are no positions such as superiors or subordinates, but without realizing it, there are unbalanced relationships in which the driver must always comply with any policy and there is not given space for deliberation before changing existing policies

The relationship between the Gojek branch of Surakarta drivers and companies is inharmonious, but productivity is still maintained. This is because the driver only works according to the maximum points. The driver must share his income with the company and the target work system, so that the driver only works according to the maximum point limit of 20 points a day, more than 20 points, they don't get a bonus.

On the other hand, the driver agrees that this online motorcycle transportation is regulated under the authority of the Government. Based on field findings, there is no official trade union, so there is no official relationship in tripartite institutions between the government, drivers, companies and consumers. The government does not have an official role in resolving disputes that occur between the driver and the company. Likewise, consumers do not have insurance from the company if they 
have an accident. In this case, consumers consider it not a problem, so those interested in online ojek services are still increasing.

\section{Discussion}

The discussion in this study refers to the framework of thinking and the relation of problems to theory and conceptual. Elements in industrial relations that want to be seen by using propositions in Blau's social exchange theory include power, domination, conflicts of interest, values, norms, social rewards, trust and social bonds and rational socio-economic concepts such as profit and loss.
Through these elements, the principles of exchange in the partnership agreement offered are balanced or not; and knowing the relationships that all parties have in harmony or not. Thus the output to be achieved in this study is if the creation of harmonious industrial relations, then the productivity of workers will increase. But if industrial relations are inharmonious and power imbalances occur, then worker productivity will decline.

The company considers the distribution of 90:10 made by Gojek with the partnership agreement has greatly benefited the driver. But most of the Gojek drivers said that the cooperation

Figure: Framework of Thinking

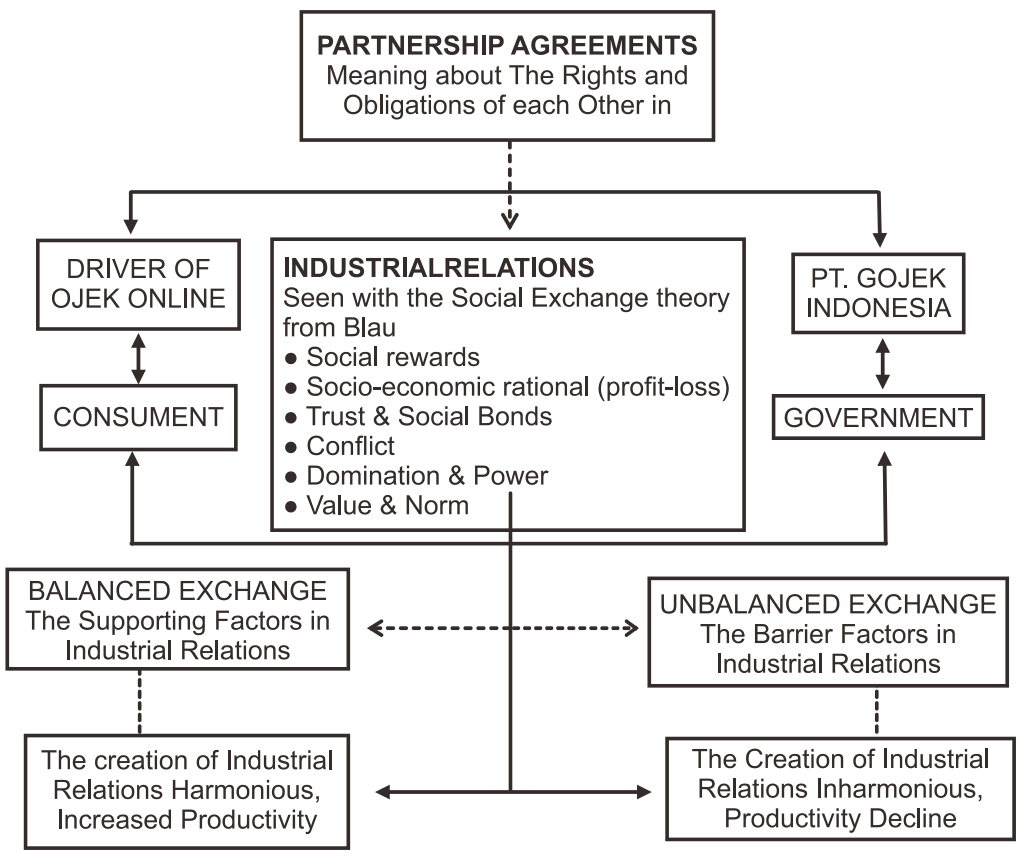


system offered by Gojek was still detrimental to the driver. This is because the partnership agreement made is not based on the results of a mutual agreement (unbalanced exchange). This agreement is made by the Gojek company. So that any policies offered must be forcibly followed (power). While the driver, must have all the attributes and equipment such as motorcycles, cellular phones, helmets, jackets to driving licenses. Each party rationalizes profit and loss, this is because each party has an interest that if the exchange that are built is unbalanced (rewards, dominate) it will give birth to conflict. Thus the trust of each other that has been built will be lost.

The driver considers their position as a partner, not a worker. So they feel that the partnership cooperation system offered by Gojek like a system of employee cooperation (rational profit-loss). If indeed the cooperation that is built leads to the work system of the employee, the driver wants to get the right to social security, such as accident, health, death and pension plan. So, the drivers agree more if transportation online arranged under the government authority. In this case, the element of the driver's trust in the Gojek company decreases, so the driver believes his fate will prosper if under the authority of the government (trust the government).

The government does not have an official role in resolving disputes that occur between the driver and the company. Likewise, consumers do not have insurance from the company if they have an accident. In this case, consumers consider it not a problem, so those interested in online ojek services are still increasing (social bonds $\&$ trust). Industrial relations involves a number of the concept, for example the concept of justice and equality, power and authority, individualism and collectivity, rights and obligations, and integrity and trust. This is in line with the elements contained in the social exchange theory which is used as a problem analysis tool in this study which is used as a problem analysis tool in this research where rights and obligations in the partnership agreement are a social exchange. in this case, it can be seen that the exchange is balanced or unbalanced . based on the results of research, exchanges were built between PT. Gojek Indonesia with ojek online drivers is not balanced and the relationship that is established is less harmonious. But productivity is 
still maintained. This is because the driver must share his income with the company and the target work system, so that the driver only works according to the maximum point limit of 20 points a day. more than 20 points, they don't get a bonus.

\section{Conclusions}

Based on the research done it can be concluded, First, there are differences in understanding between the driver and the company on the Partnership Agreement, the driver feels the employment contract offered by the Gojek company has not answered the rights of the driver as a work partner or even as a worker who facilitates social security, wage system and working time arrangements. But the company considers the distribution of 90:10 made by the Gojek in the partnership agreement has greatly benefited the driver. So the concept of the Partnership Agreement is less effective if applied to the online motorcycle service industry. Second, the working relationship that exists between the driver and the Gojek company, is a work relationship such as for workers who must always submit to any company policy, not the appropriate partner relationship. In this case the partnership agreement which should be mutually beneficial to each other, have a parallel position, there are no positions such as superiors or subordinates, but without realizing it, there are unbalanced relationships in which the driver must always comply with any policy and there is not given space for deliberation before changing existing policies. Third, the relationship between the Gojek branch of Surakarta drivers and companies is inharmonious, but productivity is still maintained. This is because the driver only works according to the maximum points. On the other hand, the driver agrees that this online motorcycle transportation is regulated under the authority of the Government. Fourth, there is no official trade union, so there is no official relationship in tripartite institutions between the government, drivers, companies and consumers.

\section{Recommendation}

From the results of the study, there are several things that can be suggested, First, In order to create an Industrial Harmony and Economic Development in the company, both workers and employers must obey and implement the applicable laws and regulations including determining the most effective cooperation agreements. Second, 
The need for roles and functions of bipartite and tripartite cooperation institutions in partnership agreements. Third, Guidance and supervision by technical institutions on a consistent and continuous basis to the implementation of the provisions of applicable laws and regulations in the field of employment in both the formal and informal sectors.

\section{Reference}

Batubara, Cosmas. 2008. Hubungan Industrial. Jakarta: Jakarta: Buana Printing.

Cahyadi, Antonius \& Donny Danardono. 2009. Sosiologi Hukum dalam Perubahan. Jakarta: Yayasan Obor Indonesia.

Creswell, John W. 1994. Research Design: Qualitative and Quantitative Approaches, California: SAGE Publications, Inc.

Denzin \& Lincoln. 2009. Handbook of Qualitative Research. Yogyakarta : Pustaka Pelajar.

Djokopitojo. 1994. Hubungan Industrial dan Organisasi Ketenagakerjaan dalam Perspektif PJPT II. Jakarta: Yayasan Tenaga Kerja Indonesia dan Friedrich Ebert Stiftung.

Lincoln, Y.S. \& Guba E.G. 1985. Naturalistic Inquiry. Beverly Hills, CA; Sage.
Miles, M.B. \& Huberman, A.M. 1994. Qualitative data analysis: A sourcebook of new methods. (edisi kedua) Thousand Oaks, CA: Sage.

Nasution, S. 2003. Metode Penelitian Naturalistik Kualitatif. Bandung: Tarsito.

Ritzer, George \& J.Goodman, Douglas. 2008. Teori Sosiologi Dari teori Klasik sampai pengembangan mutakhir Teori sosial PostModern. Jakarta : Kreasi wacana Ritzer, George. 2014. Teori Sosiologi Modern. Jakarta: Kencana Prenadamedia.

Schneider, Eugene V. 1986. Sosiologi Industri. Terjemahan dari buku asli Industrial Sociology. Penyunting J.L. Ginting. Penerbit: Aksara Persada.

Simajuntak, Payaman. 2003. Manajemen Hubungan Industrial. Jakarta: Pustaka Sinar Harapan.

Soemanto, RB. 2006. Hukum dan Sosiologi Hukum Lintasan Pemikiran, Teori dan Masalah. Penerbit: UNS Press.

Suprihanto, John. 1992. Hubungan Industrial Sebuah Pengantar. Yogyakarta: BPFEUGM

Wijaya, Mahendra. 2007. Perspektif Sosiologi Ekonomi dari Masyarakat Pra Kapitalis hing- 
ga Kapitalisme Neo-Liberal. Surakarta: Lindu Pustaka.

Beuving, Joost \& Geert De Vries. 2014. Doing Qualitative Research: The Craft of Naturalistic Inquiry. Amsterdam University Press.

Kurubetti, Arti \& Nagendra, Asha. 2014. Industrial Relations at Cummins India Limited: a Case Study. Procedia Economics and Finance 11 (2014) 86-94. Symbiosis Institute of Management Studies Annual Research Conference (SIMSARCI13).

Lora, Vivian. 2018. Tinjauan Hukum Terhadap Perjanjian Kemitraan antara PT. Gojek Indonesia Cabang Medan dengan Driver Gojek. Skripsi. Universitas Sumatera Utara.
Russell, W.B., Sherry, J.F., Wallendorf, M. 1988. A Naturalistic Inquiry into Buyer and Seller Behavior at a Swap Meet. The Journal of Consumer Research, 14, 4:449-470.

Silalahi, S.L.B., Handayani, P.W.,Mu najat, Qorib. Service Quality Analysis for Online Transportation Service: Case Study of Gojek. Procedia Computer Science. $4^{\text {th }}$ information Systems International Conference 2017, ISICO 2017, 6-8 November 2017, Bali, Indonesia.

Undang-Undang Republik Indonesia No.13 Tahun 2003 Tentang Ketenagakerjaan.

Badan Pusat Statistik Data Tenaga Kerja Formal dan Informal Tahun 2018. 